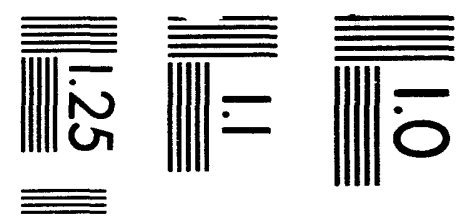

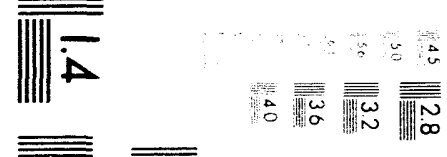

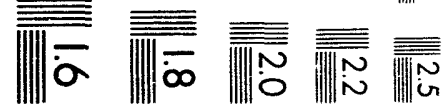



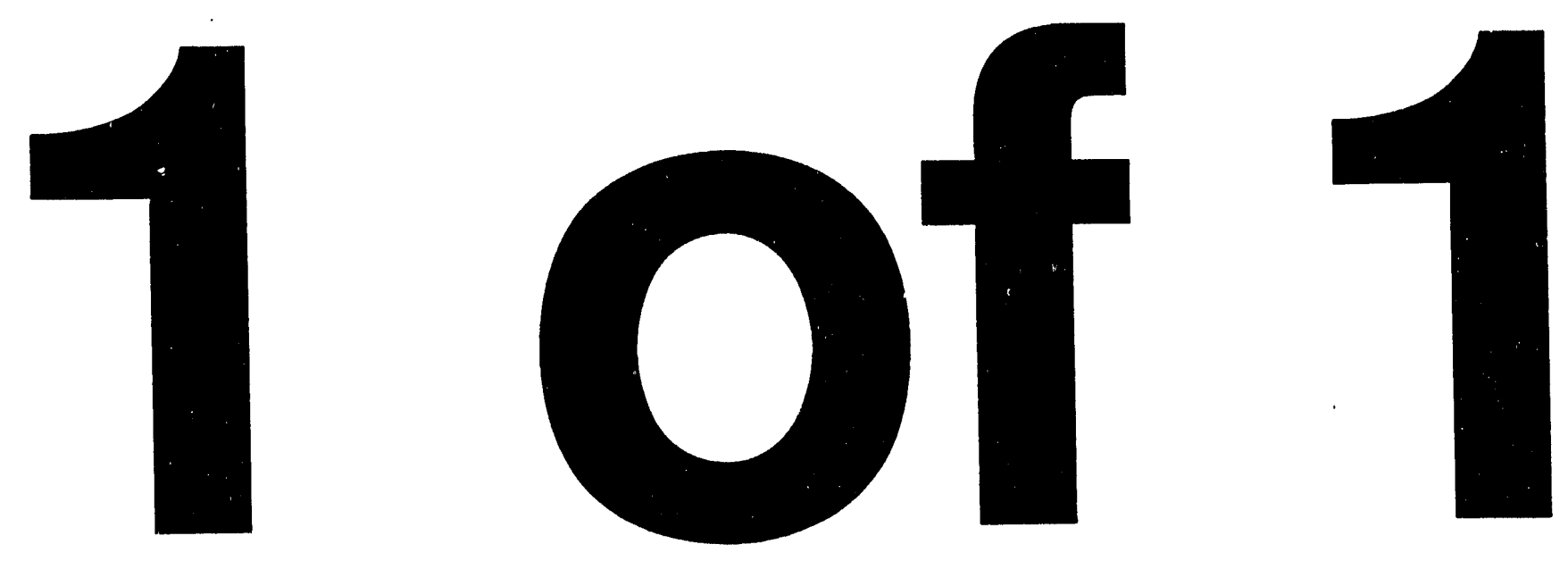


\section{Services Provided by the 222-S Laboratory for Regulatory Support}

S. P. Thomas

Date Published

November 1993

Prepared for the U.S. Department of Energy

Assistant Secretary for Environment, Safety and Healith

(2)

Westinghouse

P.O. Box 1970

Hanford Company Richland, Washington 99352

Hanford Operations and Engineering Contractor for the

U.S. Department of Energy under Contract DE-AC06-87RL10930

DISTRIBUTION OF THIS DOCUMENT IS UNLIMITED 





Document Title: SERVICES PROVIDED BY THE 222-S LABORATORY FOR REGULATORY SUPPOR'T

Prepared by:

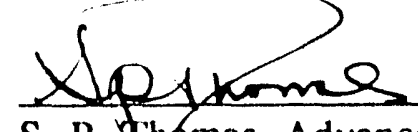

S. P. Thomas, Advanced Engineer

$9-28-93$

Effluent and Emission Monitoring

Date

Approved by:

L. P. Diediker, Manager

$\frac{9 \cdot 28.93}{\text { Date }}$

Effluent and Emission Monitoring

Reviewed by:

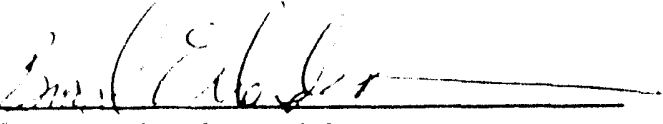

B. G. Erlandson, Manager

Regulatory Field Support

Reviewed by:

D. D. Volkman, Manager

Environmental Management Systems Integration

Reviewed by:

H. Nin

J. J. Dotian, Manager

Environmental Engineering Studies

Reviewed by: G.t. hedel

E. F. Riedel, Manager

Radioanalytical Chemistry

Reviewed by:

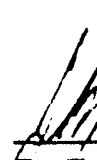

J. G. Kristofzkki, Manager

Program Support

Approved by: tf picarthol

R. P. Marshall, Jr., Manager

Analytical Operations $\frac{9-28-13}{\text { Date }}$

$\frac{9-28-93}{\text { Date }}$

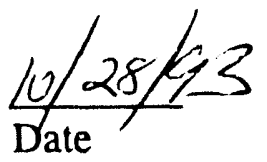

$\frac{10 / 68 / 43}{\text { Date }}$ 


\section{CONTENTS}

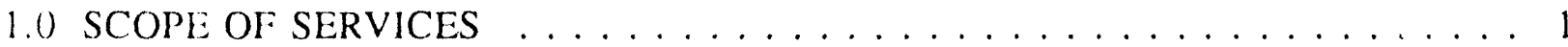

2.0 REGULATORY REPORTING REQUIREMENTS . . . . . . . . . . . . . . . . 1

2.1 Radionuclide Air Emissions Report for Clean Air Act of 1977 . . . . . . . . . . 1

2.2 Environmental Releases Report ..................... 2

2.3 Hanford Site Environmental Report . . . . . . . . . . . . . . . . . . . 2

2.4 Effluent Information System-Onsite Discharge

Information System Report . . . . . . . . . . . . . . . . . . 2

2.5 Near-Facility Operational Environmental Monitoring Report . . . . . . . . . . . 2

3.0 222-S LABORATORY SERVICES AND DATA QUALITY OBJECTIVES . . . . . 2

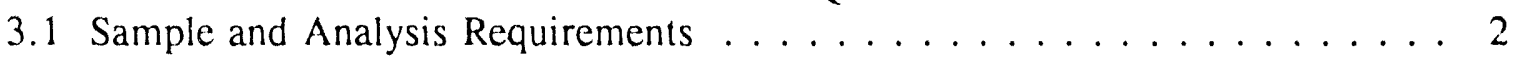

3.2 Composite Sample Requirements . . . . . . . . . . . . . . . 3

3.3 Yearend Data Reporting Due Dates . . . . . . . . . . . . . . . 3

3.4 Laboratory Procedures . . . . . . . . . . . . . . . . . . . . 3

3.5 Completeness of Analytical Data . . . . . . . . . . . . . 3

3.6 Quality Control .......................... 4

3.7 Access to Raw Data ....................... . . 4

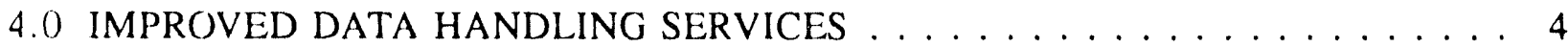

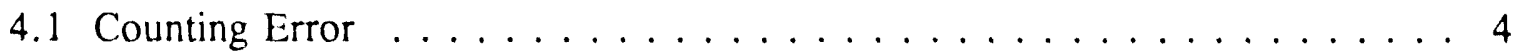

4.2 Routine Electronic Transfer of Analytical Data . . . . . . . . . . . . . . . 4

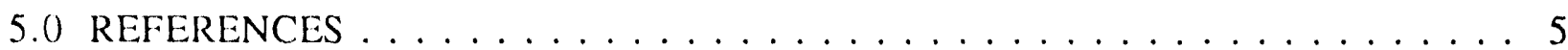

GI.OSSARY 
WHC-EP-0689

\section{LIST OF TABLES}

1 Regulatory Support Air Emission Sample and Analysis Criteria for $222-S$ Laboratory $\ldots \ldots \ldots \ldots$

2 Regulatory Support Liquid Effluent Sample and Analysis Criteria for $222-S$ Laboratory . . . . . . . . . . . . . . . . . . . 8

3 Regulatory Support Pond Vegetation and Sediment Sample and Analysis Criteria for $222-\mathrm{S}$ Laboratory $\ldots \ldots \ldots \ldots \ldots \ldots \ldots \ldots$

4 Regulatory Support Nonroutine Environmental Sample and Analysis Criteria for $222-\mathrm{S}$ Laboratory . . . . . . . . . . . . . . . . . . . . . . . . 9 


\section{SERVICES PROVIDED BY THE 222-S LABORATORY FOR REGULATORY SUPPORT}

\subsection{SCOPE OF SERVICES}

This document defines the services the 222-S Laboratory shall provide Regulatory Support (RS) and the samples RS plans to submit to the 222-S Laboratory throughout the calendar year for analysis. Analysis of effluent (liquid and air discharges) and environmental (air, liquid, animal, and vegetative) samples is required using standard laboratory procedures, in accordance with regulatory and control requirements cited in Quality Assurance Program Plan for Radionuclide Airborne Emissions Monitoring (especially Appendix G) (WHC 1993a), Quality Assurance Project Plan for Facility Effluent Monitoring Plan Activities (WHC 1992), and Operational Environmental Monitoring Program Quality Assurance Project Plun (WHC 1993b). Should changes to this document be necessary, the 222-S Laboratory or RS may amend it at any time with a jointly approved internal memo. (This document supersedes WHC-SP-0720, Statement of Work for Services Provided by the 222-S Laboratory for Environmental Assurance.)

\subsection{REGULATORY REPORTING REQUIREMENTS}

It is essential for the 222-S Laboratory to meet the due dates specified. The analytical data required by those due dates are necessary to maintain compliance with environmental release reporting commitments mandated by regulatory agencies and the U.S. Department of Energy (DOE). Variances to technical criteria or due dates in this document must be documented by the 222-S Laboratory and approved or acknowledged by RS as unavoidable.

\subsection{Radionuclide Air Emissions Report for the Clean Air Act of 1977}

This report documents radionuclide air emissions from the Hanford Site and the resulting effective dose equivalent to any member of the public from those emissions. This report complies with the reporting requirements of the Code of Federal Regulations, Title 40, "Protection of the Environment," Part 61, "National Emissions Standards for Hazardous Air Pollutants," Subpart H, "National Emission Standards for Emissions of Radionuclides Other Than Radon From Department of Energy Facilities." 


\subsection{Environmental Releases Report}

The purpose of this report is to fulfill the effluent discharge reporting requirements of DOE Order 5400.1 (DOE 1988) and to summarize the compliance status of effluent releases from Westinghouse Hanford Company (Westinghouse Hanford) facilities with respect to the administrative control value guidelines given in WHC-CM-7-5, Environmental Compliance.

\subsection{Hanford Site Environmental Report}

Pacific Northwest Laboratory annually compiles and publishes this report for DOE, in compliance with DOE Order 5400.1 (DOE 1988).

\subsection{Effluent Information System-Onsite Discharge Information System Report}

Each year Westinghouse Hanford transmits this report electronically to Idaho National Engineering Laboratory in Idaho Falls for inclusion in the Effluent Information SystemOnsite Discharge Information System (EIS-ODIS) database, in compliance with DOE Order 5484.1 (DOE 1983).

\subsection{Near-Facility Operational Environmental Monitoring Report}

Westinghouse Hanford publishes this report annually. The report provides a yearly summary of sampling and analysis of soil, vegetation, ambient air, etc. near Westinghouse Hanford facilities.

\subsection{2-S LABORATORY SERVICES AND DATA QUALITY OBJECTIVES}

The 222-S Laboratory shall provide the following analytical services when analyzing low-level environmental and effluent samples from RS.

\subsection{Sample and Analysis Requirements}

All services necessary shall be provided to complete the analytical requirements listed in Tables 1 through 4. Analyses shall be performed in accordance with applicable requirements and procedures contained in the references listed in section 1.0 above. Analytical results shall be expressed in the units shown for the respective minimum 
detectable concentrations (MDC) in the tables. (By September 30th of each year, RS will provide updated analytical requirements to the 222-S Laboratory that identify the analytes to be measured in samples from various radioactive effluents and emissions in the 200 Areas.)

\subsection{Composite Sample Requirements}

Air emission composite samples for the first three quarters shall be reported to RS within the second month following the end of the sampling quarter. All monthly liquid samples shall be reported to RS within 45 days after the end of the sampling month.

\subsection{Yearend Data Reporting Due Dates}

The due dates for submission of yearend analysis results to RS on weekly samples collected up through December 31 st are:

- Air emission data . . . . . . . . . . . . . . . . . February 18, 1994

- Liquid effluent data . . . . . . . . . . . . . . . . . . . . February 25, 1994

- Environmental data (pond vegetation and sediment) . . . . . . March 18, 1994

The analysis results from any weekly sample collected on or after January 1st of the succeeding new year will be applied to that year.

\subsection{Laboratory Procedures}

Use laboratory analytical procedures that are:

- In compliance with EPA Method 114, Section 4.0, "Quality Assurance Methods," 40 CFR Part 61, Appendix B (specifically, 4.4 and 4.5), and applicable requirements and procedures contained in the references in listed section 1.0 above

- Appropriate to the sample medium and size and the analysis requirements listed in Tables 1 through 4.

\subsection{Completeness of Analytical Data}

For completeness of analyses, fulfill the following objective:

For all RS-related samples received, produce a minimum of $90 \%$ usable analytical data. 


\subsection{Quality Control}

Quality control (QC) test results and laboratory intercomparison scores shall be provided quarterly. The QC tests shall be for accuracy, precision, completeness (see section 3.5 above), and background. Test results should be presented in bar-line graph style. All tust shall be in accordance with applicable requirements and procedures contained in the rulerences listed in section 1.0 above.

RS does submit duplicate effluent and environmental samples for analysis. The 222-S Laboratory does not know the identity of these samples when it analyzes them.

\subsection{Access to Raw Data}

As needed, RS shall have access to any $222-\mathrm{S}$ Laboratory raw data related to RS samples.

\subsection{IMPROVED DATA HANDLING SERVICES}

The 222-S Laboratory shall provide RS with improved data handling services that affect analytical counting error and routine electronic transmission of analysis data.

\subsection{Counting Error}

Provide by December 1, 1993, the counting error associated with each radioanalytical result. (Counting error is but one component of total propogated error, for which a definition is being developed that will be acceptable to both the 222-S Laboratory and RS.)

\subsection{Routine Electronic Transfer of Analytical Data}

Implement routine electronic download of all analytical data to RS by December 1 , 1993. Electronically transmit all calendar-year 1993 data to RS by January 31 , 1994, but without counting errors on data for the first three quarters of 1993. 


\subsection{REFERENCES}

Clean Air Act of 1977, 42 USC 7401 et seq.

DOE, 1988, General Environmental Protection Program, DOE Order 5400.1, U.S. Department of Energy, Washington, D.C.

DOE, 1983, Environmental Protection, Safery and Health Protection Information Reporting Requirements, DOE Order 5484.1, U.S. Department of Energy, Washington D.C.

40 CFR 61, "National Emissions Standards for Hazardous Air Pollutants," Title 40, Code of Federal Regulations, Part 61, as amended, U.S. Environmental Protection Agency, Washington, D.C.

40 CFR 61, "Quality Assurance Methods," Title 40, Code of Federal Regulations, Part 61, as amended, Appendix B, U.S. Environmental Protection Agency, Washington, D.C.

WHC-CM-7-5, Environmental Compliance, Westinghouse Hanford Company, Richland, Washington.

W'HC, 1993a, Quality Assurance Program Plan for Radionuclide Airborne Emissions Monitoring, WHC-EP-0536-1, Westinghouse Hanford Company, Richland, Washington.

WHC, 1993b, Operational Environmental Monitoring Program Quality Assurance Project Plan, WHC-EP-0538-1, Westinghouse Hanford Company, Richland, Washington.

WHC, 1992, Quality Assurance Project Plan for Facility Effluent Monitoring Plan Activities, WHC-EP-0446 Revision 1, Westinghouse Hanford Company, Richland, Washington. 
Table 1. Regulatory Support Air Emission Sample and Analysis Criteria for 222-S Laboratory

\begin{tabular}{|c|c|c|c|c|c|}
\hline \multicolumn{6}{|c|}{ Air emission sample and analysis criteria } \\
\hline Sample size & Type of analysis & $\begin{array}{c}\text { Samples/year } \\
\text { (delivery } \\
\text { frequency) }\end{array}$ & $\begin{array}{c}\text { MDC } \\
(\mu \mathrm{Ci} / \mathrm{mL})^{\mathbf{a}}\end{array}$ & $\begin{array}{c}\text { TT } \\
\text { (days) }\end{array}$ & $\begin{array}{c}\text { Unit price } \\
\text { (\$) }\end{array}$ \\
\hline \multirow{11}{*}{$\begin{array}{l}\text { Nominal } 2 \mathrm{cfm} \\
\text { for period of } \\
\text { collection, } \\
\text { unless } \\
\text { otherwise } \\
\text { indicated }\end{array}$} & $\begin{array}{c}\text { Total } \alpha \\
\text { and } \\
\text { total } B\end{array}$ & $\begin{array}{c}5,200 \\
(100 / \text { week })\end{array}$ & $\begin{array}{l}2.0 \mathrm{E}-15 \\
\text { and } \\
1.9 \mathrm{E}-14\end{array}$ & 14 & 25 \\
\hline & ${ }^{\infty} \mathrm{Sr}$ & $\begin{array}{c}72 \\
\text { (18/quarter) }\end{array}$ & $1.9 \mathrm{E}-14$ & 60 & 150 \\
\hline & $\begin{array}{c}\text { Gamma spec } \\
\left({ }^{137} \mathrm{Cs}\right)\end{array}$ & $\begin{array}{c}72 \\
\text { (18/quarter) }\end{array}$ & $7.0 \mathrm{E}-15$ & 60 & 50 \\
\hline & ${ }^{239,240} \mathrm{Pu}$ & $\begin{array}{c}112 \\
(28 / \text { quarter })\end{array}$ & $4.0 E-15$ & 60 & 150 \\
\hline & Total U & $\begin{array}{c}12 \\
\text { (3/quarter) } \\
\end{array}$ & $7.0 \mathrm{E}-8 \mathrm{~g} / \mathrm{mL}$ & 60 & 80 \\
\hline & ${ }^{3} \mathrm{H}$ & $\begin{array}{c}26 \\
\text { (1 biweekly) }\end{array}$ & 7.0 E-06 & 30 & 50 \\
\hline & ${ }^{14} \mathrm{C}$ & $\begin{array}{c}26 \\
\text { (1 biweekly) }\end{array}$ & $3.0 \mathrm{E}-13$ & 30 & 50 \\
\hline & $\begin{array}{c}\text { Ag zeolite } \\
\left({ }^{i(K} \mathrm{Ru}\right)\end{array}$ & $\begin{array}{l}260(5 / \text { week }) \\
12(1 / \text { month })\end{array}$ & $2.0 E-15$ & 30 & 50 \\
\hline & ${ }^{241} \mathrm{Am}$ & $\begin{array}{c}112 \\
\text { (28/quarter) } \\
\end{array}$ & 8.0 E-15 & 60 & 250 \\
\hline & ${ }^{147} \mathrm{Pm}$ & $\begin{array}{c}4 \\
\text { (1/quarter) }\end{array}$ & $3.0 \mathrm{E}-13$ & 60 & 150 \\
\hline & ${ }^{212} \mathrm{~Pb}$ & $\begin{array}{c}52 \\
(1 / \text { week })\end{array}$ & 5.0 E-14 & 50 & 50 \\
\hline
\end{tabular}

'Unless other units of measure are indicated

$\mathrm{MDC}=$ minimum detectable concentrations

$\mathrm{TT}=$ turnaround time 
Table 2. Regulatory Support Liquid Effluent Sample and Analysis Criteria for 222-S Laboratory

\begin{tabular}{|c|c|c|c|c|c|}
\hline \multicolumn{6}{|c|}{ Liquid effluent sample and analysis criteria } \\
\hline Sample size & $\begin{array}{l}\text { Type of } \\
\text { analysis }\end{array}$ & $\begin{array}{c}\text { Samples/year } \\
\text { (delivery } \\
\text { frequency) }\end{array}$ & $\begin{array}{c}\text { MDC } \\
(\mu \mathrm{Ci} / \mathbf{m L})^{\mathrm{a}}\end{array}$ & $\begin{array}{c}\text { TT } \\
\text { (days) }\end{array}$ & $\begin{array}{l}\text { Unit price } \\
(\$)\end{array}$ \\
\hline \multirow{8}{*}{$0.5 \mathrm{~L}$} & $\begin{array}{c}\text { Total } \alpha \\
\text { and } \\
\text { total } B\end{array}$ & $\begin{array}{c}408 \\
\text { (34/month) }\end{array}$ & $\begin{array}{c}2.0 \text { E-09 } \\
\text { and } \\
8.0 \text { E-09 }\end{array}$ & 30 & 50 \\
\hline & ${ }^{90} \mathrm{Sr}$ & $\begin{array}{c}408 \\
(34 / \text { month })\end{array}$ & 2.0 E-08 & 30 & 80 \\
\hline & $\begin{array}{c}\text { Gamma spec } \\
\left({ }^{137} \mathrm{Cs}\right)\end{array}$ & $\begin{array}{c}408 \\
\text { (34/month) }\end{array}$ & 4.0 E-08 & 30 & 50 \\
\hline & Total $U$ & $\begin{array}{c}228 \\
\text { (19/month) } \\
\end{array}$ & $1.0 \mathrm{E}-09 \mathrm{~g} / \mathrm{mL}$ & 30 & 50 \\
\hline & ${ }^{3} \mathrm{H}$ & $\begin{array}{c}180 \\
\text { (15/month) } \\
\end{array}$ & 3.0 E-05 & 30 & 50 \\
\hline & ${ }^{99} \mathrm{Tc}$ & $\begin{array}{c}48 \\
\text { (4/month) } \\
\end{array}$ & $2.0 \mathrm{E}-07$ & 30 & 150 \\
\hline & ${ }^{129} \mathrm{I}$ & $\begin{array}{c}24 \\
\text { (2/month) }\end{array}$ & 4.0 E-07 & 30 & 150 \\
\hline & ${ }^{147} \mathrm{Pm}$ & $\begin{array}{c}72 \\
\text { (6/month) }\end{array}$ & 1.0 E-06 & 30 & 150 \\
\hline \multirow{6}{*}{$1.0 \mathrm{~L}$} & ${ }^{241} \mathrm{Am}$ & $\begin{array}{c}252 \\
\text { (21/month) }\end{array}$ & $1.0 \mathrm{E}-08$ & 30 & 125 \\
\hline & ${ }^{239,240} \mathrm{Pu}$ & $\begin{array}{c}408 \\
\text { (34/month) }\end{array}$ & 5.0 E-09 & 30 & 80 \\
\hline & $\mathrm{pH}$ & $\begin{array}{c}252 \\
\text { (21/month) }\end{array}$ & NA & 60 & 50 \\
\hline & TOC & $\begin{array}{c}132 \\
\text { (11/month) }\end{array}$ & $1.0 \mathrm{E}-05 \mathrm{~g} / \mathrm{mL}$ & 60 & 80 \\
\hline & $\mathrm{NO}_{3}$ & $\begin{array}{c}168 \\
\text { (14/month) }\end{array}$ & $1.0 \mathrm{E}-06 \mathrm{~g} / \mathrm{mL}$ & 60 & 80 \\
\hline & $\mathrm{K}^{+}$ & $\begin{array}{c}12 \\
(1 / \mathrm{month})\end{array}$ & $5.0 \mathrm{E}-07 \mathrm{~g} / \mathrm{mL}$ & 60 & 80 \\
\hline
\end{tabular}

"Unless other units of measure are indicated

TOC $=$ total organic carbon

$\mathrm{MDC}=$ minimum detectable concentrations

$\mathrm{NA}=$ not applicable

$\mathrm{TT}=$ turnaround time 
Table 3. Regulatory Support Pond Vegetation and Sediment

Sample and Analysis Criteria for 222-S Laboratory

\begin{tabular}{|c|c|c|c|c|c|}
\hline \multicolumn{7}{|c|}{ Pond vegetation and sediment sample and analysis criteria } \\
\hline $\begin{array}{c}\text { Sample size } \\
(\mathbf{g}) \\
\text { (dry weight) }\end{array}$ & Type of analysis & $\begin{array}{c}\text { Samples/year } \\
\text { (delivery } \\
\text { frequency) }\end{array}$ & $\begin{array}{c}\text { MDC } \\
(\mu \mathrm{Ci} / \mathrm{mL})^{\mathbf{2}}\end{array}$ & $\begin{array}{c}\text { TT } \\
\text { (days) }\end{array}$ & $\begin{array}{c}\text { Unit price } \\
(\mathbf{\$})\end{array}$ \\
\hline 50 & ${ }^{90} \mathrm{Sr}$ & $\begin{array}{c}22 \\
\text { (annually) }\end{array}$ & $1.0 \mathrm{E}-05$ & 90 & 150 \\
\hline 200 & Gamma spec & $\begin{array}{c}22 \\
\text { (annually) }\end{array}$ & $2.0 \mathrm{E}-07$ & 90 & 150 \\
\hline 50 & $239,200 \mathrm{Pu}$ & $\begin{array}{c}22 \\
\text { (annually) }\end{array}$ & $1.0 \mathrm{E}-06$ & 90 & 150 \\
\hline 50 & Total U & $\begin{array}{c}22 \\
\text { (annually) }\end{array}$ & $1.0 \mathrm{E}-07 \mathrm{~g} / \mathrm{g}$ & 90 & 125 \\
\hline
\end{tabular}

"Unless other units of measure are indicated

$M D C=$ minimum detectable concentrations

$\mathrm{TT}=$ turnaround time

Table 4. Regulatory Support Nonroutine Environmental Sample and Analysis Criteria for 222-S Laboratory

\begin{tabular}{|c|c|c|c|c|c|}
\hline \multicolumn{6}{|c|}{ Nonroutine environmental sample and analysis criteria } \\
\hline Sample size & Type of analysis & $\begin{array}{l}\text { Samples/year } \\
\text { (delivery } \\
\text { frequency) }\end{array}$ & $\begin{array}{c}\text { MDC } \\
(\mu \mathrm{Ci} / m L)^{b}\end{array}$ & $\begin{array}{c}\text { TT } \\
\text { (days) }\end{array}$ & $\begin{array}{c}\text { Unit price } \\
\text { (\$) }\end{array}$ \\
\hline \multirow{5}{*}{ Varies } & $\begin{array}{c}\text { Total } \alpha \\
\text { and } \\
\text { total } \beta\end{array}$ & 50 & $1.0 \mathrm{E}-01$ & 90 & 80 \\
\hline & ${ }^{90} \mathrm{Sr}$ & 100 & $1.0 \mathrm{E}-06$ & 90 & 150 \\
\hline & Gamma spec & 100 & $2.0 \mathrm{E}-07$ & 90 & 150 \\
\hline & ${ }^{239,260} \mathrm{Pu}$ & 100 & $1.0 \mathrm{E}-06$ & 90 & 150 \\
\hline & Total U & 100 & $1.0 \mathrm{E}-07 \mathrm{~g} / \mathrm{g}$ & 90 & 125 \\
\hline \multicolumn{2}{|c|}{$\begin{array}{l}\text { Total analyses } \\
\text { and costs }\end{array}$} & 9,490 & & & 492,150 \\
\hline
\end{tabular}

aThis table presents information for solids analysis only (animals, nests, feces, vegetation, etc.). Occasional nouroutine air and liquid samples, however, may need analyzing by the 222-S Laboratory or preparation for analysis at another laboratory, but their total should be small compared to that of routine samples. Costs and MDCs for al.,1yzing these types of samples should be commensurate with those for routine liquid samples.

'Unless other units of measure are indicated

$\mathrm{MDC}=$ minimum detectable concentrations

$\mathrm{TT}=$ turnaround time 


\section{GLOSSARY}

\section{ACRONYMS AND INITIALISMS}

\begin{tabular}{ll} 
DOE & U.S. Department of Energy \\
EIS-ODIS & Effluent Information System-Onsite Discharge Information System \\
EPA & U.S. Environmental Protection Agency \\
NIDC & minimum detectable concentrations \\
RS & Regulatory Support \\
Tr & turnaround time \\
W'istinghouse & Westinghouse Hanford Company \\
\multicolumn{1}{l}{ Hanford } &
\end{tabular}

\section{DEFINITION OF TERMS}

Accuracy. The degree of agreement of a measurement with a true or known value.

Completeness. A measure of the amount of valid data obtained compared to the amount expected under normal conditions.

Precision. A measure of the agreement among individual measurements of the same parameters under similar conditions.

Turnaround time. Elapsed time, in days, from when a sample is received by the laboratory until the analysis results are reported to RS for that sample. 
WHC-EP-0689

\section{DISTRIBUTION}

Number of copies

\section{ONSITE}

$1 \quad$ U.S. Department of Energy-

Richland Operations Office

Public Reading Room

A $1-65$

78 Westinghouse Hanford Company

J. E. Atterberry

T6-14

M. L. Bell

T6-16

L. P. Diediker (40)

T1-30

J. N. Diven

B5-25

D. A. Dodd

T6-50

J. J. Dorian

H6-30

B. G. Erlandson

H6-20

T. G. Ibsen

T7-26

G. W. Jackson

H6-21

R. A. Jones

T6-22

J. G. Kristofzski

T6-06

W. D. Leggett

T6-07

R. P. Marshall

T6-14

C. J. Perkins

$\mathrm{X} 0-21$

J. K. Perry

H6-20

J. R. Prilucik

T6-24

E. F. Riedel

T6-50

J. W. Schmidt

H6-30

L. H. Taylor

T6-50

S. P. Thomas (10)

X0-21

G. L. Troyer

T6-50

R. E. Vogel

T6-20

Central Files

L8-15

Correspondence Control

A3-01

President's Office

B3-01

Information Release Services (3)

A3-36

Publications Services

R1-08

EPIC

H4-22 

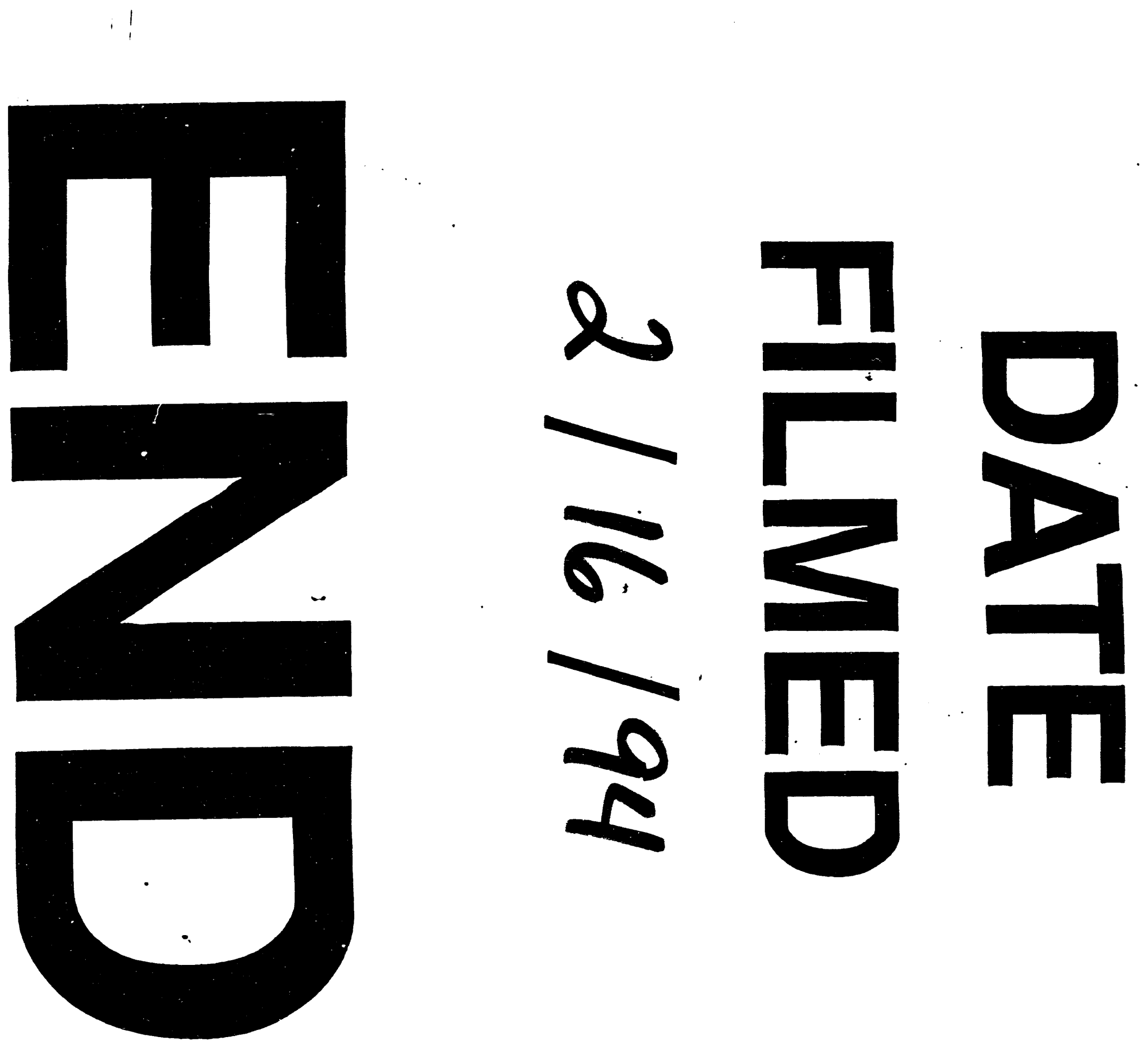
